\title{
Pemberdayaan pengrajin tenun
}

\author{
Siti Ativa Putridiani *, Yoyon Suryono \\ Program Studi Pendidikan Luar Sekolah, Program Pascasarjana, Universitas Negeri Yogyakarta. \\ Jalan Colombo No. 1, Karangmalang, Yogyakarta 55281, Indonesia \\ * Corresponding Author. Email: sitiativa387@gmail.com \\ Received: 30 April 2019; Revised: 20 November 2019; Accepted: 16 November 2019
}

\begin{abstract}
Abstrak
Penelitian ini bertujuan untuk mendeskripsikan pemberdayaan masyarakat, inovasi dalam membuat kerajinan tenun, dan faktor-faktor pendukung serta penghambat keberhasilan pemberdayaan masyarakat sentra kerajinan tenun di Desa Wisata Gamplong. Jenis penelitian adalah penelitian kualitatif metode studi kasus. Sumber data yang diteliti adalah ketua paguyuban "TEGAR", pengelola rumah kerajinan, dan pengrajin tenun. Pengumpulan data melalui wawancara, observasi serta dokumentasi. Analisis data dilakukan dengan pengumpulan data, reduksi data, penyajian data, dan kesimpulan. Instrumen yang digunakan adalah pedoman wawancara, pedoman observasi, dan dokumentasi. Keabsahan data dilakukan dengan triangulasi data, sumber dan teknik. Hasil penelitian menunjukkan bahwa proses pemberdayaan pengrajin tenun di Sentra Kerajinan desa wisata Gamplong yaitu melakukan pelatihan, melakukan pendampingan, dan evaluasi. Inovasi yang dilakukan yaitu inovasi produk yang menghasilkan design unik dan baru untuk diaplikasikan pada kerajinan tenun. Faktor pendukungnya ialah adanya event-event, potensi alam, kerajinan tenun, dan ATBM. Sedangkan faktor penghambat yaitu minimnya dukungan dari masyarakat, generasi penerus dan persaingan harga.
\end{abstract}

Kata Kunci: desa wisata, kerajinan tenun, pemberdayaan masyarakat

\section{Empowerment of weaving craftsmen}

\begin{abstract}
This study aims to describe the process of community empowerment, innovation in making woven crafts, and supporting factors and obstacles to the success of community empowerment of weaving craft centers in Gamplong Tourism Village. This type of research is a qualitative research case study method. The data sources studied were "TEGAR" community leaders, managers of craft houses, and weaving craftsmen. Data collection through interviews, observation and documentation. Data analysis with data collected, data reduction, data presentation, and conclusions. The instruments used are interview guides, observation guidelines, and documentation. The validity of the data is done with triangulation of data, sources and techniques. The results of the study show that the process of empowering weaving craftsmen in the Gamplong tourism village Craft Center is conducting training, providing-assistance, and evaluating. The innovation that is done is product innovation that produces a unique and new design to be applied to weaving crafts. The supporting factors are the existence of events, natural potential, weaving crafts, and ATBM. While the inhibiting factors are the lack of support from the community, future generations and price competition.
\end{abstract}

Keywords: community empowerment, tourism village, weaving crafts

How to Cite: Putridiani, S., \& Suryono, Y. (2019). Pemberdayaan pengrajin tenun. JPPM (Jurnal Pendidikan dan Pemberdayaan Masyarakat), 6(2), 161-169. doi:https://doi.org/10.21831/jppm.v6i2.24674

doi) https://doi.org/10.21831/jppm.v6i2.24674

\section{PENDAHULUAN}

Desa wisata merupakan suatu pengembangan desa yang banyak diminati masyarakat pada saat ini. Masyarakat desa berlombalomba untuk mengembangkan desanya menjadi desa wisata. Desa yang tidak diketahui dan tidak pernah terlihat sebelumnya akan mudah diketahui kondisinya oleh masyarakat lain dengan adanya desa wisata ini. Seperti Desa Simarjarunjung yang ada di 


\section{JPPM (Jurnal Pendidikan dan Pemberdayaan Masyarakat), 6 (2), 2019 - 162}

Siti Ativa Putridiani, Yoyon Suryono

Sumatra Utara, banyak masyarakat yang belum mengetahui keberadaan desa ini, terutama di kalangan masyarakat Sumatera Utara sendiri. Namun setelah mengalami perubahan dan perkembangan desa menjadi desa wisata, desa ini menjadi semakin terkenal di wilayah Sumatera Utara karena potensi alamnya yang mulai diberdayakan oleh masyarakat setempat. Dengan menawarkan pemandangan berupa bukit dan langit yang indah sebagai latar belakang untuk berfoto yang alami membuat desa ini banyak dikunjungi oleh wisatawan baik dari masyarakat Sumatera Utara sendiri maupun yang berasal dari daerah lain. Desa wisata ini disebut dengan Bukit Indah Simarjarunjung.

Sebagaimana yang dijelaskan oleh Hamzah dan Irfan (2018), desa wisata didasarkan pada pemanfaatan potensi yang ada di desa itu dengan ragam masyarakatnya, keindahan alam dan budaya yang ada di dalamnya sehingga bisa dijadikan sebagai daya tarik wisata. Di Indonesia, antara desa yang satu dengan yang lainnya bisa saja mempunyai struktur geografis yang sama, namun yang menjadi pembedanya adalah budaya masyarakatnya. Sehinga setiap desa memiliki keunikan dan ciri khasnya masing-masing.

Menurut (Hamzah \& Irfan, 2018; Lestari et al., 2016), tingkat pengembangan desa wisata sebagai produk pariwisata dapat dikategorikan menjadi tiga tahap, yaitu sebagai berikut. Pertama, Potensi, pada tingkat ini, suatu desa ditandai dengan: (1) Kondisi suatu desa merupakan potensi yang dapat dikembangkan untuk menjadi pengembangan infrastruktur pariwisata masih terbatas; (2) Masih/sangat sedikit turis yang berkunjung; (3) Kesadaran masyarakat akan potensi wisata tersebut masih rendah atau belum tumbuh.

Kedua, Berkembang, pada tingkat ini, sebuah desa ditandai dengan: (1) pada tahap ini, desa mulai dikenal dan dikunjungi oleh turis, baik turis lokal maupun mancanegara; (2) Sudah ada pengembangan fasilitas infrastruktur dan fasilitas pariwisata; (3) Pekerjaan dan kegiatan ekonomi mulai dilaksanakan untuk komunitas lokal; (4) Kesadaran masyarakat akan potensi pariwisata sudah mulai tumbuh; (5) Masih membutuhkan bantuan dari pihak terkait (pemerintah, swasta).
Ketiga, Lanjutan, pada tingkat ini, sebuah desa ditandai dengan: (1) Komunitas menyadari sepenuhnya potensi wisata termasuk pengembangannya; (2) Desa telah menjadi tujuan wisata populer dan dikunjungi oleh banyak wisatawan; (3) Fasilitas infrastruktur dan fasilitas pariwisata memadai; (4) Komunitas ini mandiri dan mampu untuk mengelola bisnis pariwisata secara mandiri (sumber daya manusia, produk, organisasi, dll.); (5) Mampu melakukan promosi dan pemasaran mandiri dan mengembangkan jaringan kerjasama dengan orang luar; (6) Dapat menjadi model percontohan untuk pengembangan desa wisata lainnya atau pariwisata tujuan.

Pemberdayaan menurut Widjajanti (2011, p. 16) merupakan pemberian kekuatan (power) dari seseorang yang akan menghasilkan kekuatan untuk orang lain. Seperti yang dipaparkan oleh Simon (1990); Widjajanti (2011, p. 16) pemberdayaan merupakan aktivitas refleksi, suatu proses yang mampu diinisiasikan dan diertahankan hanya oleh subjek yang mencari kekuatan atau penentuan diri sendiri (self-determination). Pemberdayaan adalah suatu proses untuk meberikan daya/kekuasaan (power) kepada pihak yang lemah (powerless), dan mengurangi kekuasaan (disempowered) kepada pihak yang terlalu berkuasa (powerful) sehingga terjadi keseimbangan (Anwas, 2013; Djohani, 2003).

Menurut Labonte (1989, pp. 87-88), pemberdayaan memiliki makna "kemampuan untuk memilih", atau "untuk meningkatkan kapasitas seseorang untuk mendefinisikan, menganalisis, dan menindaki masalah seseorang. Kita tidak dapat "memberdayakan" siapa pun, untuk menganggap begitu melucuti orang dari kapasitas mereka untuk memilih. Pemberdayaan adalah sebuah kata kerja yang bisa diperuntukkan bagi kelompok dan individu yang hanya dapat memberdayakan diri mereka sendiri. Peran kita mungkin untuk memelihara proses ini dan menghilangkan hambatan, yang pertama adalah kebutuhan kita sendiri untuk menentukan masalah bagi masyarakat.

Desa wisata merupakan salah satu tempat yang sangat tepat untuk diadakan program pemberdayaan masyarakat. Karena desa 


\section{JPPM (Jurnal Pendidikan dan Pemberdayaan Masyarakat), 6 (2), 2019 - 163 \\ Siti Ativa Putridiani, Yoyon Suryono}

wisata sangat dekat dengan masyarakat, berada di lingkungan masyarakat. Masyarakat akan sangat merasa diapresiasi mengenai keterlibatan yang dilakukan oleh masyarakat untuk desa wisata. Dan peran dari masyarakat ini akan berdampak baik bagi desa wisata. Pada masa sekarang ini, semua masyarakat dan semua desa tengah berlombalomba untuk membuat desa wisata. Ada yang membuka desa wisata berdasarkan potensi desa yang sudah ada, baik bentukan alam yang terjadi secara alami, budaya, adat istiadat, dan bangunan bersejarah. Namun ada juga yang dengan secara sengaja membuka desa wisata seperti kampung ramah anak, kampung cyber, wisata kuliner, wisata edukasi, dan sebagainya. Terkhusus di Daerah Istimewa Yogyakarta, ada banyak jenis desa wisata yang sudah ada, hampir semua jenis desa wisata ada di provinsi ini, baik yang sudah lama dibangun maupun yang baru saja dibangun, mulai dari wisata religi, wisata alam, wisata kuliner, sampai wisata kerajinan.

Kecamatan Moyudan merupakan salah satu kecamatan yang ada di Kabupaten Sleman yang memiliki berbagai sentra kerajinan. Ada 3 desa yang sudah dinobatkan sebagai desa wisata yang memiliki sentra kerajinan, dua diantaranya adalah desa yang memiliki potensi kerajinan kain tenun, yaitu di Desa Wisata Sangubanyu dan Desa Gamplong. Sedangkan satu desa lainnya yaitu desa Malangan, yang memiliki potensi kerajinan anyaman bambu, seni tempa keris, dan lain-lain. Di Desa Wisata Sangubanyu, terdapat sekitar 40 alat tenun yang disediakan oleh pengelola industri, namun yang digunakan hanya ada 4-10 alat tenun saja yang digunakan. Ini dikarenakan persaingan yang ketat, dan semakin berkurangnya warga sekitar yang berminat untuk menekuni kegiatan menenun di desa Sangubanyu. Generasi muda pun tak lagi tampak di rumah kerajinan kain tenun ini, para generasi muda di desa ini lebih tertarik untuk bekerja di tempat lain dan menjadi karyawan di sebuah supermarket daripada mengasah keterampilan dan memiliki usaha sendiri, padahal di Desa Sangubanyu sudah ada potensi kain tenun yang berkualitas dan terkenal sampai ke luar Pulau Jawa. Hingga saat ini, masih ada masyarakat yang berminat dan tertarik untuk membuat kain tenun di Sangubanyu. Meskipun para pembuat kain tenun ini hanya ada 4 orang yang aktif dan sudah berusia lanjut, namun mereka masih bersemangat untuk melanjutkan perjuangan untuk membuat kain tenun. Pada masa kejayaannya, Desa Sangubanyu memiliki berbagai rumah kerajinan, tetapi karena persaingan yang ketat, minat terhadap kain tenun semakin berkurang, secara perlahan desa ini kehilangan rumah produksi kain tenun dan hanya menyisakan satu rumah kerajinan kain tenun saja. Di rumah produksi ini dikelola oleh dua orang yang usianya sudah tidak lagi muda, namun masih bersemangat untuk menekuni dan melanjutkan usaha kerajinan mereka. Hasil produksi yang mereka hasilkan berupa kain bakal atau kain setengah jadi, mereka juga menerima pesanan untuk membuat pakaian jadi seperti seragam untuk pernikahan dan lain sebagainya. Mengenai hal ini, Nurul H (2012) berpendapat bahwa saat ini yang menjadi penghambat pengembangan tenun adalah kurangnya sumber daya manusia yang berminat untuk menenun terutama dari kalangan generasi muda. Apabila hal ini terjadi, maka akan dikhawatirkan kerajinan tenun akan punah karena tidak ada lagi yang mau dan bisa menenun.

Sedangkan di Desa Wisata Gamplong, ada 23 industri kerajinan yang masih aktif dengan berbagai macam jenis kerajinan seperti kerajinan kain tenun, kerajinan dari enceng gondok dan lain sebagainya. Industriindustri ini terdapat di beberapa rumah warga dalam satu desa. Oleh karena di desa ini banyak yang memiliki rumah produksi kerajinan, desa ini disebut dengan sentra kerajinan atau pusat kerajinan. Kualitas dari hasil produksi di desa ini pun sangat tinggi dan sudah mengekspor ke berbagai wilayah. Di desa Gamplong juga terdapat kerajinan kain tenun dengan menggunakan ATBM atau alat tenun bukan mesin, jadi alat tenun ini masih sangat tradisional. Alat ini juga menarik wisatawan yang berkunjung untuk mencoba menggunakan alat ini, tentunya dipandu oleh karyawan yang bekerja di rumah kerajinan ini. Karyawan yang menenun di salah satu rumah produksi kain tenun ini juga sudah berusia lanjut, namun hasil produksi yang dibuat lebih menarik dan mengikuti 


\section{JPPM (Jurnal Pendidikan dan Pemberdayaan Masyarakat), 6 (2), 2019 - 164 \\ Siti Ativa Putridiani, Yoyon Suryono}

perkembangan zaman misalnya seperti tas, kain syal, outer dan lain sebagainya. Di desa wisata ini juga akan dibuka tempat wisata baru yang bernuansa kampung Jawa tradisional. Awal dari pembuatan tempat wisata ini bermula dari tempat untuk lokasi syuting film kerajaan di Jawa, tempat tersebut juga akan dibuka untuk umum sebagai tempat spot foto yang baru dikalangan masyarakat, sehingga masyarakat bisa merasakan situasi di Jawa pada zaman dahulu. Ini akan menjadi daya tarik bagi wisatawan untuk berkunjung, sekaligus untuk menarik wisatawan untuk melihat produksi lokal Desa Gamplong. Harapannya, desa ini memiliki peningkatan pendapatan dengan berbagai potensi yang sudah dimiliki, dan memiliki keberlanjutan untuk masa yang akan datang.

Namun dari segi kesejahteraan masyarakatnya, Indonesia masih jauh dari kata sejahtera. Kemiskinan merupakan salah satu permasalahan besar bagi masyarakat di Indonesia. Menurut Martin dan Schuman (Alqauri, 2017; Anwas, 2013; Budiningsih, 2019) kemiskinan di tingkat global memiliki perbandingan antara $20: 80$, yaitu $20 \%$ penduduk dunia menguasai $80 \%$ kekayaan dunia, sementara $80 \%$ sisanya hanya menguasai $20 \%$ kekayaan dunia. Ini artinya hanya sedikit orang yang mampu menguasai atau Mengendalikan kekayaan alam, baik itu dinegaranya sendiri, maupun di negara orang lain. Hal ini dapat mendorong orang-orang yang memiliki kekuasaan tersebut untuk menguasai negara lain, maka terjadilah penjajahan atas kekayaan yang dimiliki oleh negara lain. Dan negara yang dijajah akan mengalami kemiskinan seperti apa yang dialami oleh negara kita, Indonesia. Banyak orang yang berasumsi bahwa Indonesia sudah merdeka puluhan tahun yang lalu dari penjajah dari Belanda dan Jepang, dan berfikir bahwa Indonesia sekarang ini adalah negara yang sedang berproses sebagai negara yang sedang berkembang, baik itu dari sektor ekonomi, politik, industri, pendidikan dan lain sebagainya. Tetapi, tak sedikit pula orang yang berasumsi bahwa Indonesia tengah dijajah oleh negara lain secara terselubung atau tersembunyi. Ini ditandai dengan banyaknya warga negara asing yang mulai masuk ke Indonesia, perusahaanperusahaan besar pun dikelola oleh warga negara asing. Pemerintah Indonesia sudah melakukan berbagai hubungan kerjasama dengan negara-negara maju dan berkembang, namun kerjasama itu tentu ada dampaknya.

Tujuan dari penelitian ini untuk mengetahui secara mendalam mengenai proses pemberdayaan pengrajin tenun di Desa Wisata Gamplong, mengetahui secara mendalam mengenai inovasi yang sudah dilakukan masing-masing industri kerajinan di desa wisata Gamplong, menggali faktor-faktor pendukung dan penghambat Desa Wisata Gamplong masih terus ada dengan industri kerajinan sampai sekarang ini.

\section{METODE}

Jenis penelitian ini adalah penelitian kualitatif dengan menggunakan metode studi kasus. Waktu penelitian dilaksanakan pada September s/d Oktober 2018 dan bertempat di 3 rumah industri kerajinan yang termasuk dalam sentra kerajinan Desa Wisata Gamplong yaitu Rumah Ketua Paguyuban “TEGAR" (Giono Craft), Ragil Jaya, dan Oglek Craft.

Sumber data yang diteliti adalah ketua paguyuban "TEGAR", 2 orang pengelola dari 2 rumah kerajinan yang berbeda, dan 2 pengrajin tenun dari rumah kerajinan yang berbeda. Pengumpulan data melalui wawancara yang mendalam, observasi serta dokumentasi. Analisis data dilakukan dengan pengumpulan data, reduksi data, penyajian data, dan kesimpulan. Instrumen yang digunakan adalah pedoman wawancara, pedoman observasi, dan dokumentasi. Keabsahan data dilakukan dengan triangulasi data, sumber dan teknik.

\section{HASIL DAN PEMBAHASAN}

\section{Proses Pemberdayaan Pengrajin Tenun Pada Sentra Kerajinan di Desa Wisata Gamplong}

Dari hasil penelitian yang telah dilakukan oleh Sulistyani dan Wulandari (2017), proses pemberdayaan mengarah pada serangkaian langkah-langkah yang ditempuh dalam mengubah masyarakat yang kurang atau belum berdaya menuju keberdayaan. Berdasarkan hasil penelitian Oleh (2014); Sulistyani dan Wulandari (2017) proses pemberdayaan masyarakat terdapat tahap-tahap 


\section{JPPM (Jurnal Pendidikan dan Pemberdayaan Masyarakat), 6 (2), 2019 - 165}

Siti Ativa Putridiani, Yoyon Suryono

yang harus dilalui, tahapan tersebut meliputi: (1) Tahap penyadaran dan tahap pembentukan perilaku menuju perilaku sadar dan peduli sehingga merasa membutuhkan kapasitas diri; (2) Tahap transformasi kemampuan berupa wawasan pengetahuan, kecakapan keterampilan agar terbuka wawasan dan memberikan keterampilan dasar sehingga dapat mengambil peran di dalam pembangunan; (3) Tahap peningkatan kemampuan intelektual, kecakapan keterampilan sehingga terbentuklah inisiatif dan kemampuan inovatif untuk mengantarkan pada kemandirian.

Berdasarkan hasil penelitian yang telah dilakukan, proses pemberdayaan berawal dari proses penyadaran yang dilakukan oleh pihak asing yang berasal dari Australia. Pada awalnya pihak asing tersebut datang ke desa Gamplong dan meminta pengrajin tenun setempat untuk membuat tas dengan menggunakan bahan serat alam, karena pada waktu tahun 1998 terjadi krisis moneter dan pihak asing tersebut berfikir untuk membuat tas dengan menggunakan bahan-bahan yang murah, dan serat alam dipilih sebagai bahan utama untuk membuat suatu kerajinan. Hal ini sebagaimana yang diungkapkan oleh Pak Giono dalam wawancara yang telah dilakukan, bahwa "Setelah produk kerajinan sudah jadi, produk tersebut dijual oleh pihak asing Australia ke daerah asal mereka dan menjadi barang yang paling dicari dan diminati banyak orang, setelah itu kerajinan serat alam pun diproduksi secara massal. Kemudian banyak pembeli-pembeli yang datang dari luar negeri mencari barang-barang yang terbuat dari serat alam, misalnya enceng gondok, lidi, mendhong, akar wangi, dan barangbarang tersebut ditenun dan dibawa lalu dijual ke luar negeri. Banyaknya pengunjung pada masa itu, maka tahun 1991 oleh Bupati Sleman dinamakan desa cinderamata, 3 tahun kemudian oleh dinas pariwisata ditetapkan desa kerajinan".

Dengan adanya keterlibatan dari pihak asing, yang merupakan Agent of Change di desa Gamplong, ini membuat masyarakat sadar bahwa tenun dan kerajinannya merupakan salah satu yang bisa dijadikan sumber pencaharian bagi masyarakat di Desa Gamplong dan memiliki prospek ke depan yang dapat meningkatkan taraf perekonoian masyarakat Gamplong.

Keberadaan kerajinan tenun diharapkan dapat membantu proses pemberdayaan para pengrajin di Desa Wisata Gamplong. Untuk mengetahui proses pemberdayaan tersebut, maka dapat dianalisis pula tahapantahapannya sebagai berikut.

Tahap Penyadaran dan Pembentukan Perilaku

Pada tahap ini, proses yang terjadi yaitu adanya kesadaran masyarakat untuk merubah kondisi mereka agar menjadi lebih baik lagi. Oleh karena itu, masyarakat membentuk paguyuban agar memudahkan kegiatan masyarakat lebih terorganisir. Setelah membentuk paguyuban yang dinamakan paguyuban TEGAR, pengurus paguyuban membangkitkan kepedulian masyarakat terhadap kerajinan tenun didesanya sebagai upaya untuk membangun kembali eksistensi kerajinan tenun. Selain itu, dengan mengikutsertakan pengrajin tenun agar memahami pentingnya pembangunan desa apabila dilakukan bersama secara kelompok.

Kegiatan yang sudah dilakukan pengelola rumah kerajinan tenun yang sudah terdaftar di paguyuban yaitu mengikuti pelatihan yang diadakan oleh dinas pariwisata sehingga dapat menunjang pengetahuan pengelola rumah kerajinan dan dapat menerapkannya.

\section{Tahap Transformasi Kemampuan}

Pada tahap ini, perwakilan pengrajin yang mengikuti pelatihan dari dinas pariwisata mulai mengimplementasikan hasil dari pelatihan tersebut untuk mentransferkan ilmu yang didapat kepada pengrajin yang lain. Paguyuban TEGAR berperan sebagai fasilitator antara para pengrajin dengan pengunjung (wisatawan yang ingin belajar menenun atau belajar membuat kerajinan tenun) melalui kegiatan kursus atau pelatihan singkat yang diadakan oleh Paguyuban TEGAR.

\section{Tahap Peningkatan Kemampuan}

Pada tahap ini, pengrajin tenun melatih kemampuannya di tempatnya masing-masing, sehingga timbul kemandirian pada 


\section{JPPM (Jurnal Pendidikan dan Pemberdayaan Masyarakat), 6 (2), 2019 - 166 \\ Siti Ativa Putridiani, Yoyon Suryono}

pengrajin tenun. Kemandirian tersebut membuat pengrajin tenun mampu membentuk inisiatif, memunculkan ide-ide baru, melahirkan kreasi-kreasi kerajinan tenun yang menarik, dan melakukan inovasi-inovasi di dalam membuat kerajinan tenun, dan lebih berani dalam membuat inovasi produk tenun yang baru. Misalnya, sebelumnya belum ada kreasi tas untuk handphone, namun sekarang sudah ada dibuat kreasi tas anyaman handphone yang terbuat dari lidi.

Jadi, proses pemberdayaan yang terjadi di desa Gamplong yang melibatkan Paguyuban TEGAR akan dijelaskan sebagai berikut.

\section{Melakukan Pelatihan}

Proses pelatihan ini melibatkan dinas pariwisata, dan kegiatan yang dilakukan yaitu sebagai berikut. Pertama, melakukan pelatihan bagi beberapa anggota dan perangkat paguyuban untuk mengikuti pelatihan-pelatihan yang diadakan oleh dinas pariwisata, maupun dari tempat wisata lainnya. Kemudian hasil dari pelatihan tersebut diterapkan dan dikembangkan di desa wisata Gamplong.

Kedua, mengadakan pertemuan untuk mensosialisasikan kepada para penenun dan anggota paguyuban untuk ikut berpartisipasi dalam setiap kegiatan yang diadakan oleh paguyuban. Kegiatan yang dilakukan yaitu turut membantu wisatawan yang berkunjung untuk mengikuti pelatihan membuat kerajinan atau yang mau belajar menenun dengan pelayanan yang terbaik, sehingga wisatawan merasa nyaman ketika sedang belajar menenun, dan dapat berkunjung lagi di lain kesempatan.

\section{Melakukan Pendampingan}

Pada proses pendampingan, perangkat paguyuban mendampingi para penenun dalam setiap pelaksanaan kegiatan di sentra kerajinan, baik itu ketika sedang berinteraksi dengan para pengunjung maupun ketika sedang menenun menggunakan Alat Tenun Bukan Mesin (ATBM).

Evaluasi

Pada proses ini, perangkat paguyuban kembali mengadakan pertemuan dengan anggota paguyuban untuk mengevaluasi kegiatan yang sudah berlangsung, sekaligus mengumpulkan permasalahan-permasalahan yang terjadi selama kegiatan kerajinan berlangsung agar dicarikan solusinya bersama. Untuk mengevaluasi hasil tenun yang dibuat, dilakukan pada saat penenun sedang membuat tenun.

Berdasarkan hasil wawancara dan pembahasan tersebut, dapat disimpulkan bahwa proses pemberdayaan pengrajin tenun dimulai dari mengikuti kegiatan pelatihan, lalu melakukan pendampingan, serta evaluasi sebagaimana yang telah dipaparkan pada penjelasan di atas.

\section{Inovasi Kerajinan di Desa Wisata Gamplong}

Dari hasil penelitian yang sudah dilakukan dapat diketahui bahwa inovasi kerajinan di desa wisata Gamplong ini yaitu inovasi produk. Sebagaimana yang telah dijelaskan bahwa inovasi produk merupakan peningkatan kualitas produk ataupun penambahan pada variasi produk yang disesuaikan dengan kebutuhan dari pembeli atau pun konsumen (Suryono \& Tohani, 2016).

Upaya yang dilakukan untuk keberlanjutan sentra kerajinan ini yaitu dengan membuat design-design terbaru. Inovasi yang sudah dilakukan agar produk kerajinan bisa bersaing dengan kerajinan-kerajinan lain yaitu dengan menyediakan bentuk produk yang beragam dan menggunakan bahan lain yang juga lebih murah serta ramah lingkungan.

Produk-produk di Desa Wisata Gamplong telah mengalami banyak perubahan dari tahun ke tahun, sehingga untuk corak khusus, corak asli, maupun corak yang menjadi ciri khas Gamplong itu sudah tidak ada. Jadi untuk corak khusus kain tenun ini tidak ada sehingga para pengrajin menggunakan motif-motif umum seperti bunga. Inovasi pun akan terus menerus dikembangkan terutama dari segi produk kerajinan tenun yang akan dijual agar eksistensinya dapat bertahan untuk kedepannya.

Berdasarkan hasil pemaparan tersebut, dapat ditarik suatu kesimpulan bahwa inovasi produk pada kerajinan tenun yang banyak dihasilkan di sentra kerajinan desa wisata Gamplong, di mana inovasi produk tersebut 


\section{JPPM (Jurnal Pendidikan dan Pemberdayaan Masyarakat), 6 (2), 2019 - 167}

Siti Ativa Putridiani, Yoyon Suryono

menghasilkan design-design unik dan baru untuk diaplikasikan pada kerajinan tenun.

\section{Faktor Pendukung dan Penghambat Pemberdayaan Pengrajin Tenun pada Sentra Kerajinan di Desa Wisata Gamplong}

Faktor Pendukung

\section{Adanya event-event}

Faktor pendukung yang bersumber dari adanya penyelenggaraan event-event besar seperti Tur de Merapi di Gamplong, studio alam Gamplong yang dijadikan sebagai tempat syuting pembuatan film sekaligus tempat wisata yang menyediakan spot foto bersetting lokasi syuting secara tidak langsung dapat membuat desa wisata Gamplong tetap eksis dan semakin diminati meskipun sebagian dari event-event tersebut diselenggarakan tidak rutin setiap hari dan hanya pada saatsaat tertentu, namun setiap kerajinan memiliki peluang mengikuti event-event tersebut dengan membuka bazaar hasil kerajinan. Ini juga kesempatan besar bagi desa wisata Gamplong untuk menunjukkan hasil kerajinan tenun yang menjadi ciri khas desa wisata ini agar menjadi semakin berkembang.

\section{Potensi alam}

Selain itu, faktor pendukung lainnya yaitu potensi alam berupa lahan kosong dan aliran-aliran sungai di sekitar Gamplong yang dapat dikelola dengan baik dan diolah menjadi sumber penghasilan penunjang yang baru. Pemanfaatan lahan kosong dapat digunakan untuk pengadaan fasilitas-fasilitas pendukung yang terbaru dan unik agar semakin diminati oleh kaum milenial.

\section{Kerajinan Tenun}

Banyaknya ATBM yang ada di Desa Wisata Gamplong menjadi keunikan tersendiri bagi para wisatawan karena desa wisata Gamplong memiliki sentra kerajinan terbanyak yang dapat diolah menjadi kerajinan yang memiliki nilai guna apabila dibandingkan dengan desa wisata lain. Ada berbagai macam kerajinan yang ada di desa wisata Gamplong selain kerajinan tenun yang paling mendominasi, diantaranya seperti kerajinan rajut, tekstil dan diolah menjadi tempat tisu, tas, tempat tabungan, souvenir dan lain sebagainya.

ATBM

Para pengrajin tenun ini tentu sangat bergantung pada kelestarian ATBM (Alat Tenun Bukan Mesin) karena ATBM merupakan sumber kehidupan bagi masyarakat di desa Gamplong. Meskipun yang mereka dapatkan tidak banyak namun setidaknya masyarakat ini bisa mencari sumber penghasilan secara mandiri dan tidak bergantung pada orang lain.

\section{Faktor Penghambat}

\section{Dukungan Warga}

Faktor pertama yang dapat menghambat perkembangan desa wisata ini yaitu tidak semua warga memiliki kesadaran untuk mengembangkan desa wisata kerajinan. Hal ini disebabkan hanya beberapa masyarakat penenun saja yang dapat merasakan keuntungan langsung dari desa wisata ini, sehingga masyarakat belum menyadari keuntungan dari adanya pembangunan desa wisata.

Pihak paguyuban TEGAR sudah berupaya untuk mensosialisasikan tentang desa wisata pada setiap kali ada pertemuan, namun tidak semua warga mau untuk mengembangkan desa wisata. Apabila semua warga bisa memiliki pemahaman yang sama, tujuan atau visi misi yang sama, maka harapannya pengembangan desa wisata Gamplong ini jadi lebih optimal karena adanya keterlibatan dari seluruh masyarakat di desa wisata Gamplong.

\section{Generasi Penerus}

Generasi penerus sekarang sudah tidak berorientasi lagi pada kegiatan tenun. Karena para orang tua pengrajin sudah tidak melihat lagi harapan pada kain tenun yang sudah mulai berkurang peminatnya meskipun anak mereka sebagian sudah bisa menenun. Pengrajin tenun banyak yang menganggur dikarenakan usia yang sudah tidak muda lagi dan generasi yang dapat menenun sekarang ini sudah mulai berkurang. Selain itu, pengrajin merasa permintaan sudah tidak sebanyak yang dulu sehingga sudah kehilangan semangat untuk menenun kembali. Kendala yang terjadi pada saat proses produksi dikarenakan 


\section{JPPM (Jurnal Pendidikan dan Pemberdayaan Masyarakat), 6 (2), 2019 - 168}

Siti Ativa Putridiani, Yoyon Suryono

pengrajinnya lebih banyak yang berusia lanjut. Anak-anak para pengrajin yang sudah berusia lanjut pun sebenarnya bisa menenun, namun dikarenakan sudah menikah dan berpindah rumah sehingga tidak menenun kembali.

\section{Harga}

Faktor penghambat selanjutnya yaitu ada di AFTA (ASEAN Free Trade Area). Perubahan harga yang ada di AFTA juga berpengaruh terhadap kerajinan yang ada di Gamplong ini, produk-produk Cina juga banyak yang masuk ke Indonesia sehingga berpengaruh pada produk lokal. Selain perubahan harga pada AFTA, perubahan harga pun terjadi ke pedagang tas yang lebih memilih untuk menjual produk yang murah tanpa melihat sisi kualitasnya. Maksudnya, kebijakan harga yang ada di AFTA yang terus berubah karena pergerakan harga dollar juga berpengaruh pada harga yang sudah dipatok di desa wisata Gamplong. Sementara itu, Cina juga memproduksi kerajinan (misalnya tas, dompet, dan sebagainya) dengan harga yang lebih murah namun dengan kualitas yang sederhana. Ini mengakibatkan konsumen lebih memilih produk yang lebih murah tersebut daripada produk yang dihasilkan di desa Gamplong.

\section{SIMPULAN}

Proses pemberdayaan pengrajin tenun di Sentra Kerajinan desa wisata Gamplong yaitu: (a) Melakukan pelatihan, dengan melakukan pelatihan bagi beberapa anggota dan perangkat paguyuban, kemudian hasil dari pelatihan tersebut diterapkan dan dikembangkan di Desa Wisata Gamplong, serta men-sosialisasikan kepada para penenun dan anggota paguyuban untuk ikut berpartisipasi dalam setiap kegiatan yang diadakan oleh paguyuban. (b) Melakukan pendampingan, dengan mendampingi para penenun dalam setiap pelaksanaan kegiatan di sentra kerajinan, baik itu ketika sedang berinteraksi dengan para pengunjung maupun ketika sedang menenun menggunakan Alat Tenun Bukan Mesin (ATBM). (c) Evaluasi, dengan mengevaluasi kegiatan yang berlangsung, sekaligus mengumpulkan permasalahan-permasalahan yang terjadi selama kegiatan kerajinan berlangsung agar dicarikan solusinya bersama. Untuk mengevaluasi hasil tenun yang dibuat, dilakukan pada saat penenun sedang membuat tenun.

Inovasi yang sudah dilakukan agar masing-masing rumah kerajinan mampu bersaing di Desa Wisata Gamplong yaitu inovasi produk. Inovasi produk terjadi karena produk yang dihasilkan dari serat alam berbeda dengan produk yang sebelumnya namun tidak mengurangi kualitas dari produk yang dihasilkan, dan inovasi produk tersebut menghasilkan design unik untuk diaplikasikan pada kerajinan tenun.

Faktor pendukung Desa Wisata Gamplong masih terus ada dengan industri kerajinannya sampai sekarang ini di antaranya ialah adanya pengadaan acara, potensi alam, kerajinan tenun, dan ATBM. Sedangkan faktor penghambat dalam perkembangan desa wisata Gamplong ini yaitu kurangnya dukungan masyarakat, tempat pemasaran, generasi penerus dan harga.

\section{DAFTAR PUSTAKA}

Alqauri, M. H. (2017). Implementasi program pemberdayaan ekonomi masyarakat melalui usaha ternak kambing lembaga dompet dhuafa waspada di Desa Sidomulyo Kecamatan Binjai Kabupaten Langkat. Universitas Islam Negeri Sumatera Utara.

Anwas, O. M. (2013). Pemberdayaan masyarakat di era global. Alfabeta.

Budiningsih, W. (2019). Strategi pemberdayaan masyarakat melalui dana desa sebagai upaya pengentasan kemiskinan (Studi kasus pada Desa Melung Kecamatan Kedungbanteng, Kabupaten Banyumas). IAIN Purwokerto.

Djohani, R. (2003). Partisispasi, pemberdayaan, dan demokrastisasi komunitas: reposisi participatory rural appraisal (PRA) dalam program pengembangan masyarakat. Studio Driya Media untuk Konsorsium Pengembangan Masyarakat Nusa Tenggara (KPMNT).

Hamzah, A. S., \& Irfan, M. (2018). Law enforcement of constitutional court 
JPPM (Jurnal Pendidikan dan Pemberdayaan Masyarakat), 6 (2), 2019 - 169

Siti Ativa Putridiani, Yoyon Suryono

decision No. 69/PUU -XII/2015 (Mixed marriage issue without marriage agreement). NOTARIIL: Jurnal Kenotariatan, $3(1), \quad 1$. https://doi.org/10.22225/jn.3.1.597.1-12

Labonte, R. (1989). Community empowerment: The need for political analysis. Canadian Journal of Public Health, 8o(2), 87-88.

Lestari, G., Armawi, A., \& Muhamad, M. (2016). Partisipasi pemuda dalam mengembangkan pariwisata berbasis masyarakat untuk meningkatkan ketahanan sosial budaya wilayah (Studi di Desa Wisata Pentingsari, Umbulharjo, Cangkringan, Sleman, D.I. Yogyakarta). Jurnal Ketahanan Nasional, $\quad 22(2), \quad 137$. https://doi.org/10.22146/jkn.17302

Nurul H, N. (2012). Pesona tenun nusantara. Warta Ekspor, 3-7. http://djpen.kemendag.go.id/app_fron tend/admin/docs/publication/934139o 368693.pdf

Oleh, H. F. (2014). Pelaksanaan kebijakan alokasi dana desa (ADD) dalam memberdayakan masyarakat desa di Desa Cerme, Kecamatan Grogol, Kabupaten Kediri. Jurnal Kebijakan Dan Manajemen Publik, 2(1).

Simon, B. L. (1990). Rethinking empowerment. Journal of Progressive Human Services, 1(1), 27-39. https://doi.org/10.130o/Jo59vo1no1_04

Sulistyani, A. T., \& Wulandari, Y. (2017). Proses pemberdayaan masyarakat Desa Sitimulyo Kecamatan Piyungan Kabupaten Bantul dalam pembentukan kelompok pengelola sampah mandiri (KPSM). Jurnal Pengabdian Kepada Masyarakat (Indonesian Journal of Community Engagement), 2(2), 146-162. https://doi.org/10.22146/jpkm.27024

Suryono, Y., \& Tohani, E. (2016). Inovasi pendidikan nonformal. Graha Cendekia.

Widjajanti, K. (2011). Model pemberdayaan masyarakat. Jurnal Ekonomi Pembangunan, $12(1)$. http://hdl.handle.net/11617/1306 